\title{
SOCIAL MEDIA AND GREEN CONSUMPTION BEHAVIOR OF MILLENNIALS
}

\author{
Dr.Vijay Kumar Jain \\ Assistant Professor, Faculty of Management Studies \\ DIT University Dehradun, Uttrakhand \\ Anu Gupta \\ Research Scholar, Faculty of Management Studies \\ DIT University Dehradun, Uttrakhand \\ Dr. Vikas Tyagi \\ Associate Professor, School of Management \\ Chandigarh University, Punjab \\ Dr. Hemraj Verma \\ Associate Professor, Faculty of Management Studies \\ DIT University Dehradun, Uttrakhand
}

\begin{abstract}
Globalization and economic growth has brought substantial shifts in consumption practices, production and technology revolution in the wake of sudden spurt of social media usage among young consumers. The social media platforms have become a reliable source of communication with consumers and are shaping consumers' purchase intentions. Therefore, a framework was developed to explain and empirically verify the factors shaping green purchase intentions. Three factors Social media usage, Interpersonal Influence and E-WOM have been taken as exogenous variables. The model was tested and validated statistically with the help of structural equation modeling.Total 500 respondents were sampled to collect the data. All four hypotheses were found to be statistically significant. The impact of social media usage was found to be most influential on purchase intention. The findings of the study will aid marketers to better understand how social media plays an important role in shaping consumers' purchase intentions and how social media can be leveraged in a better way to encourage green consumption among millennials.
\end{abstract}

Keywords: Social Media Usage, Interpersonal Influence, e-WOM, SEM

\section{INTRODUCTION}

Globalization and economic development have led to significant shifts in consumer behavior, manufacturing methods and a revolution in technology, with a large range of internet use and market acceptance (Shao, 2009; Shang, Chen and Liao, 2006; Schlosser, 2005). Social media has become one of the most effective consumer marketing gears and is increasingly entwined into the normal lives of consumers, changing the way customers and marketers interact with each other (Ismail, 2017). Social media has arisen as an electronic communication platform in this scenario by sharing information, ideas and content created by users through networking and blogging (S. Krishnamurthy and W. Dou, 2008). More than $70 \%$ of American millennials use social networking channels, frequently with several accounts on various sites and smartphone apps (The Nielsen Company, 2015).

Millennials were the first buyers to rise in the world of global interdependence, which made them more open to ethical issues than others (Johnson et.al, 2019). In addition, the childhood years of millennials lead to a rise in media coverage of environmental concern and predisposition (Lu, Bock, \& Joseph, 2013). Millennials are thought to be mindful of environmental concerns (Schoolman, Tysman, Schwimmer, \& Shriberg, 2016). Millennials are more than just familiar with environmental concerns while creating buying decisions or are mindful ofCSR and resilience. The Nielsen study (2015) has shown that millennials are the most reluctant generation to pay a premium for green items, particularly when produced by companies with positive social 
and environmental contributions. Furthermore, millennials follow employers that pose simple, optimistic messages about their CSR and environmental initiatives.

Bedard et.al (2018) has analyzed the motives of millennials to purchase green goods, the use of social media as a marketing tool and its consequences but still there is, however, a gap in a research exploring the role of social media and behavioral regulation by millennials as potential drivers of their consumer behavior (Lee, 2008 and 2010; Ellison, Steinfield, \& Lampe, 2007). Prusa, P., \& Sadílek, T. (2019) have studied the perception of green consumers and presented a model for green consumption. Analysis into millennial consuming patterns is important due to their increased purchasing power and impact of this generation on the total workforce (The Nielsen Company, 2015). Several studies in the past have revealed that social media affects the buying behavior of millennials but despite that there is an unwillingness among millennials towards green consumption. Since more than any other generation, social media is essential for the everyday lives of millennials (Helal et.al, 2018), therefore, the study is required to understand the green consumption behavior and how social media affects it.

Looking at the importance of social media, it is important to understand how social media as a platform shapes young consumers' perception towards eco-friendly products. This study aims to find the factors shaping consumer perception towards green purchase intention and its subsequent impact on green purchase behavior. The findings of the study would help marketers to frame strategies to motivate millennials towards green products.

\section{Theoretical Background and Hypothesis Development \\ Social Media Usage and Green Purchase Intention}

Singh et al. (2012) stated that social media has pioneered how companies and people connect between green and non-green goods, encouraging consumers to buy more engaging and competitive products. Organizations are searching for expanded visibility through various social platforms to reach customers across digital networks. In 2012, Smith and Brower stated that millennials in particular favor green businesses with a large web inclusion. Customers mainly use social media to get and ingest product-related information (Heinonen, 2011). Therefore, the online existence of a product is crucial for the final customer buying decisions. Wang et al., (2012) said that interactions between social media influence purchasing decisions both directly (by urging buyers to respond to peers) and implicit (by the amount of time spent contemplating and studying a product). Furthermore, social media experiences are linked positively to brand faith and product attitude (Wang et al., 2012, Hajli, 2014). Because of the immersive existence of the social media listed earlier (Sonnenburg and Singh, 2012), both corporations and peers networks play a very important role in shaping buying decisions made by principle of social influence is used to analyze the use of social media as social media contains an excess of the populated networks, powerful virtual proximities, and content created by the users. Therefore, customers would eventually build a trust in a green brand by regular, supportive interactions delivered across social media platforms (Kang \& Hur, 2012).So the principle of social influence indicates that the use of social media has a strong effect capacity in a definitive partnership. The above literature has helped us to deduce that social media usage affects purchase intentions and propose the hypothesis that:

\section{H1: Social media usage is positively related to green purchase intentions.}

\section{Interpersonal Influence and Green Purchase Intention}

Katz and Lazarsfeld proposed that customers pursue marketing recommendations to satisfy the wish to join a group or strengthen the group relationship. It proposed further that opinion-seeking conduct could be studied as a mechanism of socialization (Flynn et al. 1996). Via the cycle of product socialization and contact, opinion seekers may be encouraged to create or reinforce their bonds with the community and gradually become indirectly sensitive to normative influences (Bertrandias, L.; Goldsmith, R.E., 2006). This claim is further reinforced by practical confirmation that interpersonal factors can influence customer buying decisions. Green customers trying to join a green group may demonstrate their desire to buy green goods as a signal that they want to adhere to the social expectations set by the green community they want to belong to. 
Green consumers should therefore be driven to constantly collect renewable information from diverse outlets to select the right products.

This claim is backed by the research by Vining and Ebreo (1990), which found that people who were more dedicated to green habits, such as recycling, were more likely to turn to friends or environmental conservation details than others. Feick et al. (1986) reported that opinion seekers gather knowledge or views from informal sources to determine goods and make purchasing decisions. Evidence indicates that informative interpersonal factors may affect customer decision-making processes in product reviews, product selection, and purchasing decisions .Therefore, green customers are extremely likely to rely on climate experts or opinion leaders' knowledge to purchase climate goods in the green sense. In the light of above literature, the hypotheses is proposed:

H2: Interpersonal influence is positively related to green purchase intention.

\section{E-WOM and Green Purchase Intention}

Word-of-mouth contact is essentially a message about the product or service of a client, or about the business itself, in the form of feedback about the success of the product, hospitality, integrity, level of operation, and certain issues viewed and encountered by someone else. The messages sent may be either positive or pessimistic depending on what the message-giver thinks about the programs it embraces. As mainstream messaging has been phased behind, the shift in messaging paradigms has also shifted customer behavior (Sweeney JC, Soutar GN, Tim M., 2008). Till date, consumers favor word-of-mouth, since the distribution of personal-experience-based information is considered credible. Word-ofmouth contact may have a significant impact on consumers. Wang (2015) clarified that EWOM affects consumer purchasing decisions. Lamba et.al (2016) have reported that customer buying decisions were affected by EWOM. With the EWOM, consumers may get a lot more intimacy with other customers and get a quicker response on product information. Where information on products or services is not clear, consumers usually seek more data and citations from other source information, besides official sources of product details. Accordingly, this study considered that the electronic word-of-mouth could spread much more information to consumers which further affect the purchase intention. The EWOM affects the purchase intention and is an antecedent of purchase intention. Therefore, we suggest the hypothesis:

\section{H3: EWOM is positively related to Purchase Intention.}

\section{Green Purchase Intention and Green Purchase Behavior}

Yadav and Pathak (2017) define intention as the readiness of a person to conduct a specific behavior. As it catches the motivation to act, including readiness to participate and heightened effort, a person is willing to exercise. As per the theory of planned behavior, the performance is the product of actions when the action is voluntary in nature. In 2017, Yadav and Pathak, found evidence of a strong correlation in the context of green products for both behavioral intentions and green buying behavior. Consumers who are highly involved have to make a deliberate purchase without condition (Sharma and Joshi, 2017: Jain and Chamola, 2019). Green purchase intention defined as the want of customers towards acquisitions of green products. Intentions describe the driving factors that influence green buying behavior among consumers. According to the research by (Richa. C \& Samrat. B, 2018) green purchase intention facilitates green purchase behavior in a positive way. Since intention facilitates the purchase behaviors. Therefore, it is taken as antecedent of purchase behavior and the following hypothesis is proposed in support of the literature.

\section{H4: Green Purchase Intention affects green purchase behavior positively.}

\section{Conceptual Framework}

This paper has developed a framework to understand the green purchase intention of millennials. The variables were identified based on literature and are important in predicting green purchase intentions. The variables selected for the framework are: Social Media Usage, Interpersonal Influence, E-WOM, Green Purchase Intentions and Green Purchase Behavior. 


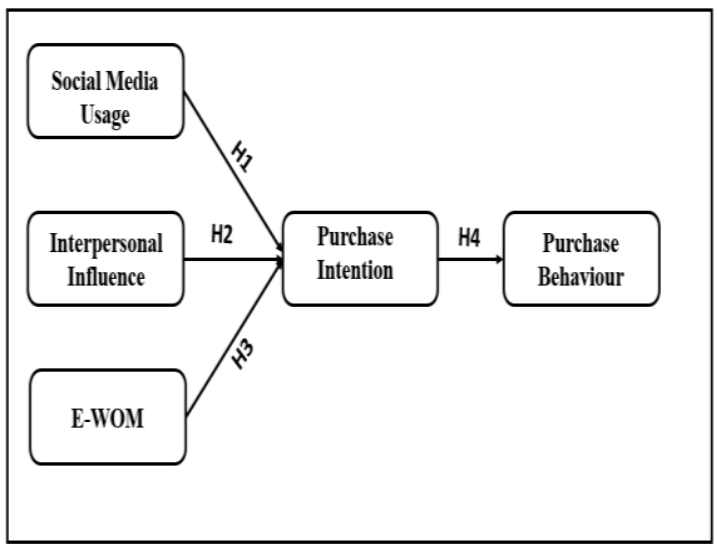

Figure 1: Conceptual Framework

\section{METHODOLOGY}

The present study has undertaken quantitative analysis on collected data. The pilot study had been administered with a sample of 50 respondents. Items were developed using existing literature for three constructs and existing scales for purchase intention and behavior had been borrowed. The questions were finalized after ensuring quality and objectivity of the instruments. The questionnaire was developed to test the propounded hypothesis.

The systematic random sampling was used to collect the data. Data was collected from students, working professionals and housewives in different parts of the country. The data were collected in the month of January and February, 2020. Total 500 respondents residing across India have answered the questionnaires.

The summary of respondents' demographics is given in Table 1.

\section{The Instrument}

The existing scales have been designed to capture the constructs taken in the study. Previous studies conducted in similarcontexts have been made for selection of these scales. Likert scales were for measurement of data. The questionnaire was composed of two parts.

Demographic details were given in the first section and second sections contains 21 items used to measure the five constructs except EWOM, all constructs were captured using four items scale. To measure social media usage, interpersonal influence and EWOM, items were developed after going through literature and in consultation with domain experts. The scales have been improved to ensemble the context and some of the items of the scales have been deleted due to low factor loadings.

Table 1: Demographic Information

\begin{tabular}{|c|l|c|c|}
\hline Variables & \multicolumn{1}{|c|}{ Category } & Frequency & (\%) \\
\hline \multirow{3}{*}{ Gender } & Male & 280 & 56 \\
\cline { 2 - 4 } & Female & 220 & 44 \\
\hline \multirow{4}{*}{ Age } & $20-30$ & 130 & 26 \\
\cline { 2 - 4 } & $30-40$ & 220 & 44 \\
\cline { 2 - 4 } & $40-50$ & 150 & 30 \\
\hline \multirow{5}{*}{ Education } & Graduate & 140 & 28 \\
\cline { 2 - 4 } & PG & 170 & 34 \\
\cline { 2 - 4 } & PhD & 150 & 30 \\
\cline { 2 - 4 } & Others & 40 & 20 \\
\hline \multirow{5}{*}{ Income } & $10,000-25,000$ & 100 & 28 \\
\cline { 2 - 4 } & $25,000-40,000$ & 119 & 29 \\
\cline { 2 - 4 } & $40,000-55,000$ & 141 & 8 \\
\cline { 2 - 4 } & 55,000 Above & 140 & 23 \\
\hline
\end{tabular}

Source: Authors' Calculations 
The constructs and its indicators have been shown in Table 2 .

Table 2

\begin{tabular}{|c|c|c|c|}
\hline Construct & & Items & $\begin{array}{c}\text { Cronbach } \\
\text { Alpha }\end{array}$ \\
\hline \multirow{4}{*}{$\begin{array}{l}\text { Social Media } \\
\text { Usage }\end{array}$} & SMU1 & I am always keen to use social media. & \multirow{4}{*}{0.85} \\
\hline & SMU2 & I often read posts shared on social media. & \\
\hline & SMU3 & Social media posts influence my opinions. & \\
\hline & SMU4 & My purchasing decisions are guided by social media. & \\
\hline \multirow{4}{*}{$\begin{array}{l}\text { Interpersonal } \\
\text { Influence }\end{array}$} & IPI1 & It exerts pressures on consumers to respondin a certain way. & \multirow{4}{*}{0.81} \\
\hline & IPI2 & $\begin{array}{l}\text { I believe that interpersonal influence affects purchase } \\
\text { decisions. }\end{array}$ & \\
\hline & IPI3 & It influences the product selection of consumers. & \\
\hline & IPI4 & I believe opinion seekersdepend on people for advice. & \\
\hline \multirow{5}{*}{ E-WOM } & E-WOM1 & $\begin{array}{l}\text { I frequently share my opinion on social media about } \\
\text { products. }\end{array}$ & \multirow{5}{*}{0.79} \\
\hline & E-WOM2 & $\begin{array}{l}\text { People share their real experiences on social media } \\
\text { platforms. }\end{array}$ & \\
\hline & E-WOM3 & $\begin{array}{l}\text { I have often used Facebook to share my opinion more than } \\
\text { any other medium. }\end{array}$ & \\
\hline & E-WOM4 & I find E-WOM content reliable. & \\
\hline & E-WOM5 & $\begin{array}{l}\text { EWOM affects the purchase decisions of consumers on } \\
\text { social media platforms. }\end{array}$ & \\
\hline \multirow{4}{*}{$\begin{array}{l}\text { Purchase } \\
\text { Intention }\end{array}$} & PI1 & $\begin{array}{l}\text { I will consider purchasing only less polluting products in } \\
\text { the coming time. }\end{array}$ & \multirow{4}{*}{0.79} \\
\hline & PI2 & $\begin{array}{l}\text { I will change my loyalty for ecological reasons to green } \\
\text { products. }\end{array}$ & \\
\hline & PI3 & $\begin{array}{l}\text { Green products must be purchased as they make less } \\
\text { environmental impact. }\end{array}$ & \\
\hline & PI4 & I think of spending more on environmental goods. & \\
\hline \multirow{4}{*}{$\begin{array}{l}\text { Purchase } \\
\text { Behavior }\end{array}$} & PB1 & I only purchase green products for my daily needs. & \multirow{4}{*}{0.79} \\
\hline & PB2 & Green products are part of my daily needs products. & \\
\hline & PB3 & $\begin{array}{l}\text { My purchasing behavior has been green for the last few } \\
\text { weeks. }\end{array}$ & \\
\hline & PB4 & I have had a green buying activity in the last six months. & \\
\hline
\end{tabular}

Source: Authors' Calculations

\section{Structural Equation Model}

The SEM bond regression and confirmatory factor analysis to measure a series of interrelationship between constructs of the proposed model. Measurement model and Structural Model are two main elements of SEM. The relationship of latent constructs to its variable is measured by measurement model whereas structural models examine the power of the relations. It also tests the strength of the relationships.

\section{The Measurement Model}

The confirmatory factor analysis has tested the proposed model. In SEM, before proceeding for relationship testing in the constructs, the model is supposed to have high degree of validity and reliability. The hypothesized model has been tested with the help of scales mentioned in the instrument sections. Total 21 items have been used to measure five constructs in the model. The proposed model has been measured using scales mentioned in the Instrument section.

The convergent validity, discriminant validity and reliability have been checked for the proposed model. Internal consistency is a measure of the reliability of diverse survey items that intend to measure the same 
characteristics. Cronbach's alpha indicates inner consistency. The Cronbach alpha score was calculated for each construct and is presented in Table 1. All constructs are good on reliability. Social Media Usage, Interpersonal Influence, EWOM, Purchase Intention and Purchase Behavior have the reliability score of $0.85,0.81,0.79,0.91$ and 0.79 respectively.

Convergent validity test the amount of commonness among the indicators of the constructs (et al., 2010). This is assessed by standardized factor loadings which further confirms the worth of indicator variables and confirms its representation of the latent constructs. All observed variables factor loading falls between 0.69 and 0.93 . It confirms the relations of individual variables to its constructs and therefore, confirms the convergent validity.

This confirms observed variables are acceptable and relate to their constructs. Therefore, convergent validity is confirmed.

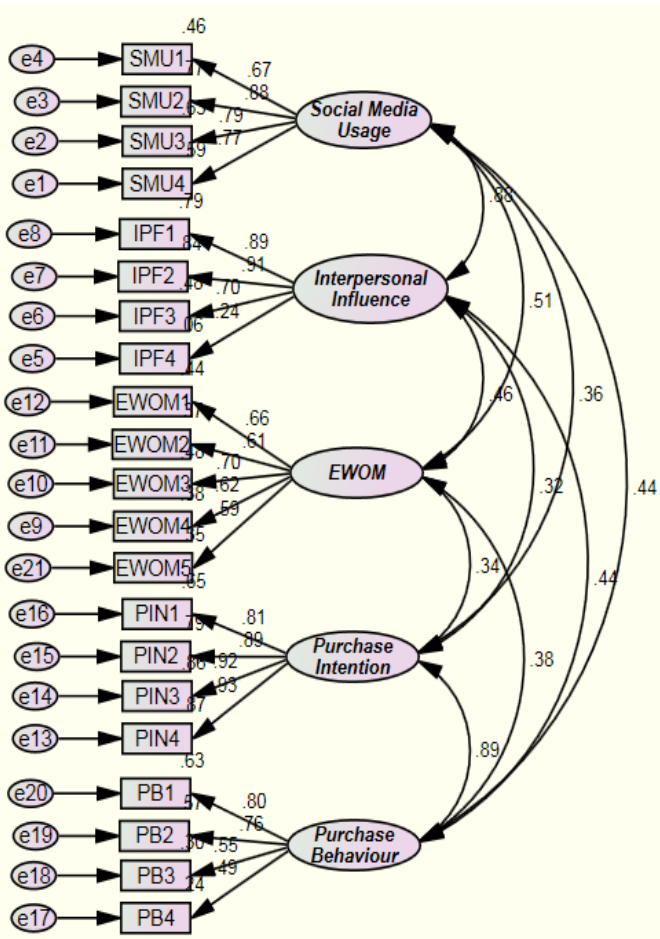

Figure 2: Measurement Model: Factors Affecting Green Purchase Intention

The model was tested for goodness of fit and

Table 3: Correlation Matrix and Average Variance Extracted

\begin{tabular}{|c|c|c|c|c|c|c|c|c|c|}
\hline & CR & AVE & MSV & ASV & SMU & IPI & EWOM & PI & PB \\
\hline SMU & 0.911 & 0.721 & 0.284 & 0.191 & 0.849 & & & & \\
\hline IPI & 0.862 & 0.611 & 0.284 & 0.184 & 0.533 & 0.782 & & & \\
\hline EWOM & 0.817 & 0.527 & 0.189 & 0.124 & 0.312 & 0.409 & 0.726 & & \\
\hline PI & 0.919 & 0.739 & 0.189 & 0.104 & 0.240 & 0.402 & 0.435 & 0.860 & \\
\hline PB & 0.938 & 0.790 & 0.326 & 0.169 & 0.496 & 0.359 & 0.295 & 0.241 & 0.889 \\
\hline
\end{tabular}

Source: Authors' Calculations

Table 4: Summary of goodness of fit indices

\begin{tabular}{|l|r|c|c|c|c|c|}
\hline \multicolumn{1}{|c|}{ Model fit Indices } & $\mathbf{X} / \mathbf{d f}$ & CFI & GFI & NFI & TLI & RMSEA \\
\hline Measurement Model & 1.90 & 0.91 & 0.931 & 0.92 & 0.933 & 0.037 \\
\hline Structural Model & 1.92 & 0.95 & 0.91 & 0.93 & 0.95 & 0.041 \\
\hline
\end{tabular}

Source: Authors' Calculations

Table 5: Summary of Testing of Hypotheses

\begin{tabular}{|c|c|c|c|l|}
\hline Paths & $\boldsymbol{\beta}$ Coefficient & t-value & p-value & Relationship \\
\hline PIN <-IPI & 0.10 & 0.285 & 0.04 & Confirmed \\
\hline PI<-SMU & 0.20 & 1.65 & 0.02 & Confirmed \\
\hline PI<-EWOM & 0.13 & 2.45 & 0.03 & Confirmed \\
\hline PB<-PI & 0.88 & 3.45 & $* * *$ & Confirmed \\
\hline
\end{tabular}

Source: Authors' Calculations 
subjected to CFI, GFI, NFI, TLI and RMSEA (Hair et al. 2010) indices. The threshold value of Chi square/df has to be less than 3 for obtaining satisfactory fit. Further, CFI, GFI, NFI and TLI should be more than 0.9. The RMSEA value must be inferior than 0.08 (Gefen \& Strab, 2000). Table 4 presents the summary of goodness of fit for measurement models. The respective Chi-square/df, CFI, GFI, NFI, TLI and RMSEA values are 1.90, $0.91,0.92,0.930 .92,0.93$ and 0.037 .

Structural Model: To confirm the propounded hypothesis in the research model, the structural model has been performed using SEM. The values of goodness of fit indices are $1.92, \quad 0.95, \quad 0.91, \quad 0.93,0.95$ and 0.041 respectively. All goodness of fit measures are within the desired range and are accepted. This proves the validity of the structural model as per the fit indices and allows us to proceed further to test the research hypothesis proposed in our research model.

Table 5 presents the summary of hypothesis testing. The beta coefficient elucidates the contribution of independent variables towards dependent variables. All hypotheses are found positive in nature. Factors such asSocial Media Usage, Interpersonal Influence, EWOM and Purchase have been found to be significant and have a different beta coefficient. The different factors contribute different weights to purchase intention towards green products.

\section{RESULTS \& DISCUSSION}

The proposed structure mirrored the effect of user-generated content on green customer behavior, due to its perceived level of ease of use, perceived utility and perceived feelings associated with social media use. The social media use has been found to be a significant predictor of purchase intention $(\beta=0.20$ : $\mathrm{p}<0.05)$.Moreover, the present research also considered the effect of the interaction between many variables on the purchasing decisions and advertisement of green goods. The results reflected that while green goods purchasing decisions primarily derive from environmental consciousness, there are certain considerations that are considered crucial in deciding the preferences of customers to buy green goods.

Despite the abundance of studies on the factors that make green goods interesting to millennials, there is little data on the basic factors that enhance the green purchase intentions of millennials above social influence and environmental interest (Lee, 2008). EWOM was found to be a significant predictor of purchase intention $(\beta=0.13: p<0.05)$ as the influence of EWOM on consumers' purchase intentions has long been known by researchers (Zhang et al., 2010). The results confirm the significance of the model highlighting the role of information and attitude as factors of EWOM on social media. Interpersonal influence was also found to be a significant predictor of purchase intention $(\beta=0.10$ : $\mathrm{p}<0.05)$ and supports the model. It was found that people who were more committed to green behaviors, such as recycling, were more likely than others to turn to friends or environmental protection information.

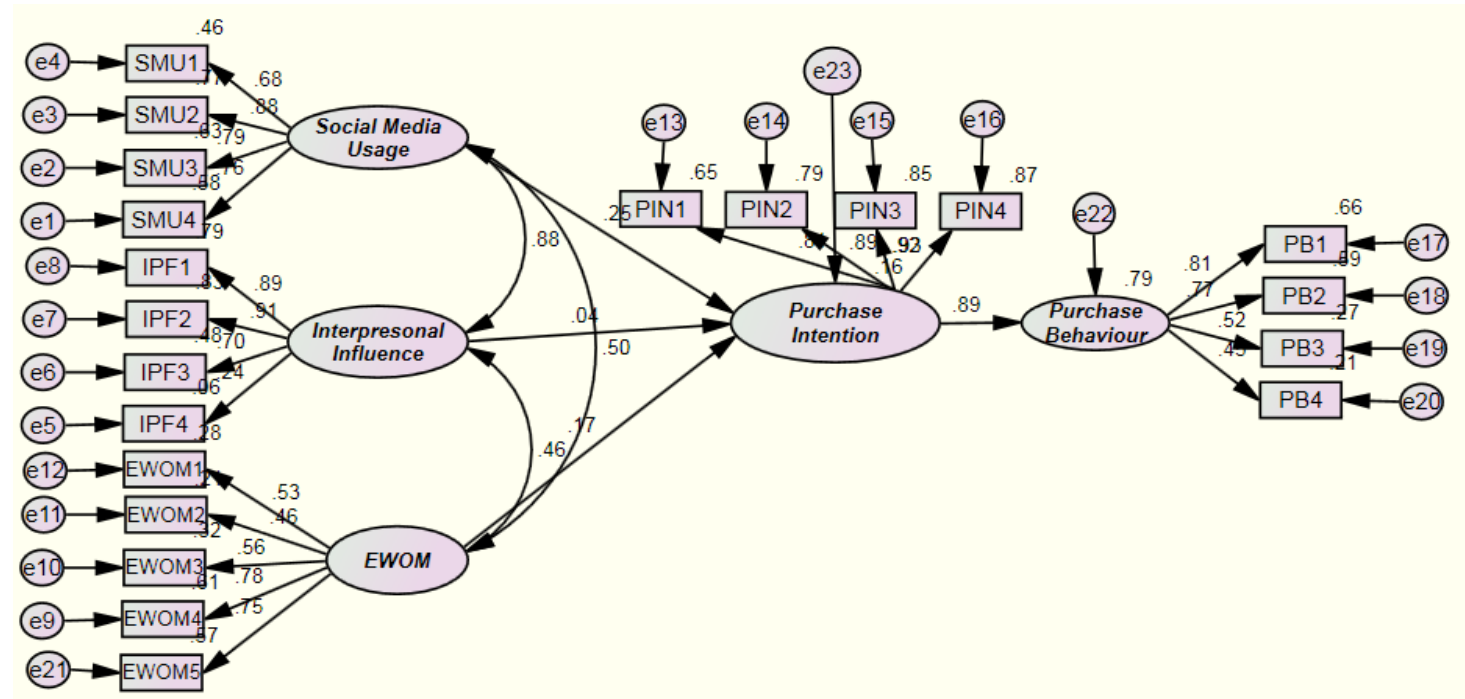

Figure 3: Structural Model: Factors affecting Green Purchase Intention 
Literature indicates that insightful interpersonal considerations can influence the decision-making process of customers in product reviews, product selection and purchase decisions.

The impact of purchase intention on purchase behavior is reported significant $(\beta=0.88$ : $\mathrm{p}<0.05)$ in the study. Researchers found evidence of a strong correlation in the context of green products for both behavioral intention and green buying behavior. Green purchase intention defined as the desire of customers to purchase green products. Intention means the driving factors that influence green buying behavior among consumers. As per the researchers, green purchase intention facilitates green purchase behavior in a positive way.

\section{CONCLUSION}

The presence of social media has made it an attractive mode of communication for companies. Companies have realized the power of social media as a platform to connect with consumers and promote their goods on social media. Social media holds huge potential for growth in time to come. As social media has become an important mode of connecting with millennials, therefore, it must be utilized to its fullest to leverage its benefits for society. The current paper has studied the role of social media in shaping millennials' purchase intentions towards green consumption. Shifting behavior towards green consumption practices will help in saving of resources, improving environment and reduction in wastage of resources.

\section{Theoretical Implications}

The current study has extended the existing literature by providing valuable insights. The study has explained the role of social media in shaping green purchase intentions of millennials. Millennials, being a significant chunk of the population, occupy an important role in consumption and have responsibility towards the environment. Therefore, this study has provided the framework needed to understand the green purchase intentions of millennials.

\section{Managerial Implications}

The adoption of green consumption has become imperative to consumers and companies both. Companies should strive through social media platforms as a part of environmental responsibility to create awareness among consumers about green consumption. As most of the consumers are present on the social media platforms. Therefore, the findings of the study would provide insights to companies about how they can use social media platforms to encourage green consumption among Indian consumers. Green consumption would be optimized with the increased environmental awareness through social media platforms.

\section{LIMITATIONS \& DIRECTION FOR FUTURE RESEARCH}

The current study is not free from the limitations. The sample size used in India is too low to represent the entire country. The large sample size could have been helped towards generalizing the findings to the population. Second, social media habits and consumption varies across countries. As this study has been carried out in India, therefore it requires replication in some other countries before generalizing the findings. The current study has only used three factors that shape purchase intention for green products. The future study must extensively use literature to add more factors to this model to enhance their understanding towards how green intentions are shaped, future studies must segregate the sample according to generation because all generations are different from each other with respect to social media usage.

\section{REFERENCE}

Bedard, S. A. N., \& Tolmie, C. R. (2018). Millennials' green consumption behaviour: Exploring the role of social media. Corporate Social Responsibility and Environmental Management, 25(6), 1388-1396.

do Paco, A., Shiel, C., \& Alves, H. (2019). A new model for testing green consumer behaviour. Journal of cleaner production, 207, 998-1006.

E. Schlosser. (2005). posting versus lurking: Communicating in a multiple audience context. Journal of Consumer Research, 32(2) 260-265.

Ellison. N.B., Steinfield, C. \& Lampe, C. (2007). The benefits of Facebook friends: social capital and college students' use of online social network sites, Journal of Computer-Mediated Communication, 12(4)1143-1168. 
Flynn LR, Goldsmith RE, Eastman JK. (1996). Opinion leaders and opinion seekers: Two new measurement scales, Journal of the Academy of Marketing Science 24(2), 137-147.

G. Shao (2009). Understanding the appeal of user-generated media: A uses and gratification perspective, Internet Research, 19(1), 7-25.

Goldsmith, R. E., \& Horowitz, D. (2006). Measuring motivations for online opinion seeking, Journal of Interactive Advertising, 6(2).

Hajli, M. (2014). A study of the impact of social media on consumers, Journal of Market research, 56(3), 387-404.

Haws, k. L, Winterich, K, P. \& Naylon, R.W. (2014). Seeing the world through green- tinted glasses: green consumption values and responses to environmentally friendly products, Journal of Consumer Psychology, 24(3): 356-354.

Heinonen, K. (2011). Consumer activity in social media: management approaches to consumers' social media behavior, Journal of Consumer Behavior, 10(6), 356-364.

Helal, G., Ozuem, W., \& Lancaster, G. (2018). Social media brand perceptions of millennials. International Journal of Retail $\mathcal{E}$ Distribution Management.

Ismail, A.R. (2017). The influence of perceived social media marketing activities on brand loyalty: the mediation effect of brand and value consciousness, Asia Pacific Journal of Marketing and Logistics, 29(1), 129-144.

Jha, Vinit Kumar Utpal. (2017). A Study on the Engagement of Indian Students on Social Media, Journal of Content, Community $\mathcal{E}$ Communication, 6 (3).

Johnson, O., \& Chattaraman, V. (2019). Conceptualization and measurement of millennial's social signaling and self-signaling for socially responsible consumption. Journal of Consumer Behaviour, 18(1), 32-42.

Kang, S. \& Hur, W.M. (2012). Investigating the antecedents of green brand equity: a sustainable development perspective. CSR and Environmental Management, 19(5), 306-316.

Kumar, J. V., \& Chamola, P. (2019). Exploring Antecedents of Responsible consumption using Structural Equation Modeling. Serbian Journal of Management, 14(1), 77-95.
Kumar, N., \& Benbasat, I. (2006). The influence of recommendations and consumer reviews on evaluations of websites, Information Systems Research, 17(4), 425-439.

Lamba B, Manav A. (2016) .A Study on Influence of e-WOM: Consumer Buying Behavior, The International Journal of Business $\mathcal{E}$ Management, 4(1):246-51.

Lu, L., Bock, D., \& Joseph, M. (2013). Green marketing: what the millennials buy, Journal of Business Strategy, 34 (6), 3-10.

Park, D.-H., Lee, J., \& Han, I. (2007). The effect of on-line consumer reviews on consumer purchasing intention: the moderating role of involvement, International Journal of Electronic Commerce, 11(4), 125-148.

Prusa, P., \& Sadílek, T. (2019). Green Consumer Behavior: The Case of Czech Consumers of Generation Y. Social Marketing Quarterly, 25(4), 243-255.

R. A. Shang, Y. C. Chen, and H. J. Liao (2006). The value of participation in virtual consumer communities on brand loyalty, Internet Research, 16(4), 398-418.

S. Krishnamurthy \& W. Dou (2008). Advertising with user-generated content: A framework and research agenda, Journal of Interactive Advertising, 8(2), 1-7.

Schoolman, E.D, Shriberg, M., Schwimmer, S. \& Tysman,M. (2016). Green cities and ivory towers: how do higher education sustainability initiatives shape millennials' consumption practices, Journal of Environmental Studies and Sciences, 6(3), 490502 ?

Shiva, A., \& Singh, M. (2019). Stock hunting or blue chip investments? Qualitative Research in Financial Markets. Vol. 12(1), pp. 1 - 23.

Singh, S., \& Sonnenburg, S (2012). Brand performances in social media, Journal of Interactive Marketing, 24(4), 189-197.

Song, M. (2017). In China, making a fashion statement, April, available at: http:// blogs.ei.columbia.

Edu/2017/04/24/in-china-making-a-fashionstatement/ (Accessed June 6, 2017).

Sweeney JC, Soutar GN, Mazzarol T. (2012). Word of mouth: measuring the power of individual messages, European Journal of Marketing, 46(1/2), 237-257. 
The Nielsen Company (2015). The Sustainability Imperative. Available at http://www.nielson.com/us/en/insights/re ports/20145/the-sustainabilityimperative.html

Wang YC. (2015). A study on the influence of electronic word of mouth and the image of gastronomy tourism on the intentions of tourists visiting Macau. Tourism. 63(1):67-80.

Wang, X., Yu. C. \& Wei. Y. (2012). Social media peer communication and impact on purchase intention: a consumer socialization framework, Journal of Interactive Marketing, 26(4), 198- 208.

Yadav, R. and Pathak, G.S. (2017). Determinants of consumer green purchase behavior in a developing nation: applying and extending the theory of planned behavior, Ecological Economics, 134(1), 114-122.

Zhang, J. Q., Craciun, G., \& Shin, D. (2010). When does electronic word-of-mouth matter? A study of consumer product reviews. Journal of Business Research, 63(12), 1336-1341. 